\title{
PENERAPAN METODE KONTEKSTUAL SEBAGAI UPAYA MENINGKATKAN PRESTASI BELAJAR PERMAINAN BOLA BASKET
}

\author{
I Wayan Sukadana \\ SMP Negeri 2 Gianyar \\ e-mail: sukadana12@gmail.com
}

\begin{abstract}
Abstrak
Tujuan Penelitian Tindakan Kelas yang dilaksanakan di SMP Negeri 2 Gianyar pada Kelas IX B Semester II Tahun Pelajaran 2017/2018 ini adalah untuk mengetahui apakah Metode pembelajaran Kontekstual dapat meningkatkan prestasi belajar Permainan Bola Basket siswa kelas IX B Semester II SMP Negeri 2 Gianyar. Metode pengumpulan datanya menggunakan observasi untuk mengevaluasi tingkat keterlibatan peserta disik secara mental dan tes prestasi belajar yang digunakan untuk mengukur tingkat pencapaian keterampilan yang dicapai peserta didik dalam proses pembelajaran. Untuk memaknai data hasil penelitian, data yang telah diperoleh dianalisis dengan metode analisis deskriptif kuantitatif, dengan menyajikan rata-rata, modus, median, dan prosentase ketuntasan belajar. Hasil yang diperoleh dari penelitian ini adalah Metode pembelajaran Kontekstual dapat meningkatkan prestasi belajar Permainan Bola Basket. Ini terbukti dari hasil yang diperoleh pada pada awalnya rata-rata 69,4 dengan prosentase ketuntasan belajar $36 \%$. Setelah diberikan tindakan pada siklus I prestasi belajar anak mengalami peningkatan menjadi rata-rata 74,2 , dengan ketuntasan belajar $72 \%$ Selanjutnya pada siklus II meningkat lagi menjadi rata-rata 82,00 dengan ketuntasan belajar mencapai $96 \%$. Hasil yang diperoleh pada siklus II ini telah mencapai indikator keberhasilan yang ditetapkan sehingga penelitian tidak dilanjutkan. Kesimpulan yang diperoleh dari penelitian ini adalah Metode pembelajaran Kontekstual dapat meningkatkan prestasi belajar Permainan Bola Basket siswa kelas IX B SMP Negeri 2 Gianyar.
\end{abstract}

Kata kunci: metode kontekstual, prestasi belajar, permainan bola basket

\begin{abstract}
The purpose of the Class Action Research conducted at Gianyar State Middle 2 in Class II B Semester II of the 2017/2018 Academic Year is to find out whether the Contextual Learning Model can improve the learning achievement of Grade IX B Basketball Games in Semester II Gianyar State Middle School 2. The data collection method uses observations to evaluate the level of involvement of mentally discharged participants and the learning achievement test used to measure the level of achievement of skills achieved by students in the learning process. To interpret the research data, the data obtained were analyzed by quantitative descriptive analysis method, by presenting the mean, mode, median, and percentage of mastery learning. The results obtained from this study are Contextual Learning Models that can improve the learning achievement of Basketball Games. This is evident from the results obtained at the beginning of an average of 69.4 with the percentage of learning completeness $36 \%$. After being given action in the first cycle, children's learning achievement has increased to an average of 74.2 , with $72 \%$ learning completeness. Furthermore, in cycle II it increased again to an average of 82.00 with learning completeness reaching $96 \%$. The results obtained in the second cycle have reached the determined success indicators so that the research is not continued. The conclusion obtained from this study is that the Contextual Learning Model can improve the learning achievement of the IX B grade basketball game of Gianyar State Middle School 2.
\end{abstract}

Keywords: contextual methods, learning achievement, basketball games. 


\section{Pendahuluan}

Menciptakan manusia Indonesia yang sangat unggul merupakan suatu tantangan dan keharusan dalam menghadapi era globalisasi, salah satunya melalui Pendidikan Jasmani, Olahraga, dan Kesehatan karena peranan Pendidikan Jasmani, Olahraga, dan Kesehatan di dalam intensifikasi penyelenggaraan pendidikan berfungsi sebagai proses interaksi antara siswa dan lingkungan yang dikelola melalui aktivitas jasmani dalam upaya menuju pembentukan manusia Indonesia seutuhnya, serta menunjang pertumbuhan dan perkembangan jasmani, mental, sosial, dan emosional yang serasi, selaras, dan seimbang (Aip Syarifudidin, 1992 : 3).

Pendidikan jasmani, olahraga, dan kesehatan adalah bagian integral dari pendidikan secara keseluruhan, bertujuan untuk mengembangkan aspek kebugaran jasmani, keterampilan gerak, keterampilan berfikir kritis, keterampilan sosial, penalaran, stabilitas emosional, tindakan moral, aspek pola hidup sehat, dan pengenalan lingkungan bersih melalui aktivitas jasmani, olahraga, dan kesehatan terpilih yang direncanakan secara sistematis dalam rangka mencapai tujuan pendidikan nasional

Pada proses pembelajaran pendidikan jasmanai, olahraga, dan kesehatan guru diharapkan bertanggung jawab membuat rencana pembelajaran yang berisikan pernyataan yang jelas tentang perilaku, aktivitas pelajaran, teknik-teknik member rangsang, dan prosedur penilaian. Namun seringkali berbagai keterampilan yang diharapkan siswa tidak mampu diberikan oleh guru, hal ini disebabkan pembelajaran Pendidikan Jasmani, Olahraga, dan Kesehatan pada umumnya berorientasi pada pendekatan konvensional. Oleh karena itu aktivitas yang diberikan dalam pembelajaran harus mendapatkan sentuhan didaktik-metodik, sehingga aktivitas yang dilakukan dapat mencapai tujuan pembelajaran.

Permasalahan yang sering dijumpai dalam pembelajaran Pendidikan Jasmani, Olahraga, dan Kesehatan yaitu rendahnya minat, motivasi, dan aktivitas belajar siswa sehingga hasil belajar siswa kurang tercapai secara optimal. Bertolak dari permasalahan tersebut, guru sebagai pengelola proses pembelajaran diharapkan dapat menciptakan sarana belajar yang merangsang minat belajar siswa dan mampu menyediakan lingkungan belajar yang menarik bagi siswa. Keberhasilan proses pembelajaran tidak terlepas dari cara guru mengajar dan siswa dalam belajar. Peran guru dalam pembelajaran yaitu membuat desain instruksional, menyelenggarakan kegiatan belajar mengajar, bertindak mengajar atau membelajarkan, mengevaluasi hasil belajar yang berupa dampak pengajaran. Peran siswa adalah bertindak belajar yaitu memahami proses belajar dan menggunakan hasil belajar sebagai dampak pengiring. Kegiatan pembelajaran dapat berjalan dengna baik dan lancar jika terjadi keharmonisan antara siswa dan lingkungan belajar yang diatur oleh guru. Salah satu langkah yang dilakukan guru agar pembelajaran berjalan efektif dan efisien adalah memahami dan menguasai bahan pelajaran, menerapkan berbagai metode, pendekatan dan strategi pembelajaran sehingga aktivitas dan hasil belajar siswa dapat tercapai secara optimal.

Berdasarkan hasil observasi di SMP Negeri 2 Gianyar mengenai proses pembelajaran Pendidikan Jasmani, Olahraga, dan Kesehatan dengan materi bola basket teknik dasar bola basket di Kelas IX B bahwa kenyataan di lapangan menunjukkan masih rendahnya prestasi belajar siswa yang ditandai dengan rendahnya hasil belajar Permainan Bola Basket yang diperoleh siswa. Ini dikarenakan guru belum menggunakan model-metode pembelajaran yang mampu membangkitkan gairah belajar siswa sehingga aktivitas belajar dan hasil belajar bola basket siswa belum tercapai secara optimal. Maka dari itu, untuk mengatasi permasalahan tersebut, solusi yang diberikan peneliti dalam penelitian ini adalah penerapan metode pembelajaran kontekstual untuk meningkatkan aktivitas dan hasil belajar Permainan Bola Basket SMP Negeri 2 Gianyar.

Adapun keunggulan dari metode pembelajaran kontekstual yaitu, siswa secara aktif terlibat dalam proses pembelajaran, siswa balajar dari teman melalui kerja keolmpok, diskusi, dan saling mengoreksi, pembelajaran dikaitkan dengan kehidupan dunia nyata, perilaku dibangun atas kesadaran sendiri, keterampilan dikembangkan atas dasar 
pemahaman, pembelajaran yang dilakukan harus mempertimbangkan pengetahuan dan kekurangan siswa, pembelajaran dapat terjadi di berbagai tempat, konteks, dan setting dalam kehidupan sehari-hari, penilaian menitikberatkan pada penilaian proses tanpa mengesampingkan penilaian produk. Dengan keunggulan dari metode pembelajaran kontekstual akan dapat meningkatkan aktivitas belajar siswa dan meningkatkan hasil belajar Permainan Bola Basket pada Kelas IX B semester II SMP Negeri 2 Gianyar.

Berdasarkan permasalahan di atas, peneliti merasa terdorong untuk melakukan penelitian yang berjudul "Penerapan Metode pembelajaran Kontekstual Sebagai Upaya Meningkatkan Prestasi Belajar Permainan Bola Basket Siswa Kelas IX B Semester II SMP Negeri 2 Gianyar tahun pelajaran 2017/2018"

Hipotesis penelitian yang diajukan pada penelitian ini adalah: apabila langkah-langkah metode pembelajaran Kontekstual diterapkan dengan maksimal sesuai teori maka prestasi belajar permainan bola basket siswa kelas IX B Semester II SMP Negeri 2 Gianyar tahun pelajaran 2017/2018 dapat ditingkatkan.

\section{Metode}

Dalam melaksanakan Penelitian Tindakan Kelas, langkah-langkah atau prosedur PTK didasarkan pada model rancangan PTK dari para ahli. Selama ini dikenal berbagai model PTK, namun pada dasarnya terdapat empat tahap yang harus dilalui yaitu (1) perencanan (planning), (2) pelaksanaan (acting), (3) pengamatan (observing), dan (4) refleksi (reflecting). Keempat tahap tersebut merupakan satu siklus dan akan dapat berlanjut kepada siklus kedua, siklus ketiga dan seterusnya sesuai dengan apa yang diinginkan dalam penelitian.

Untuk penelitian ini penulis memilih rancangan penelitian tindakan yang disampaikan Mc. Kernan seperti terlihat pada gambar berikut.

Mc. Kernan
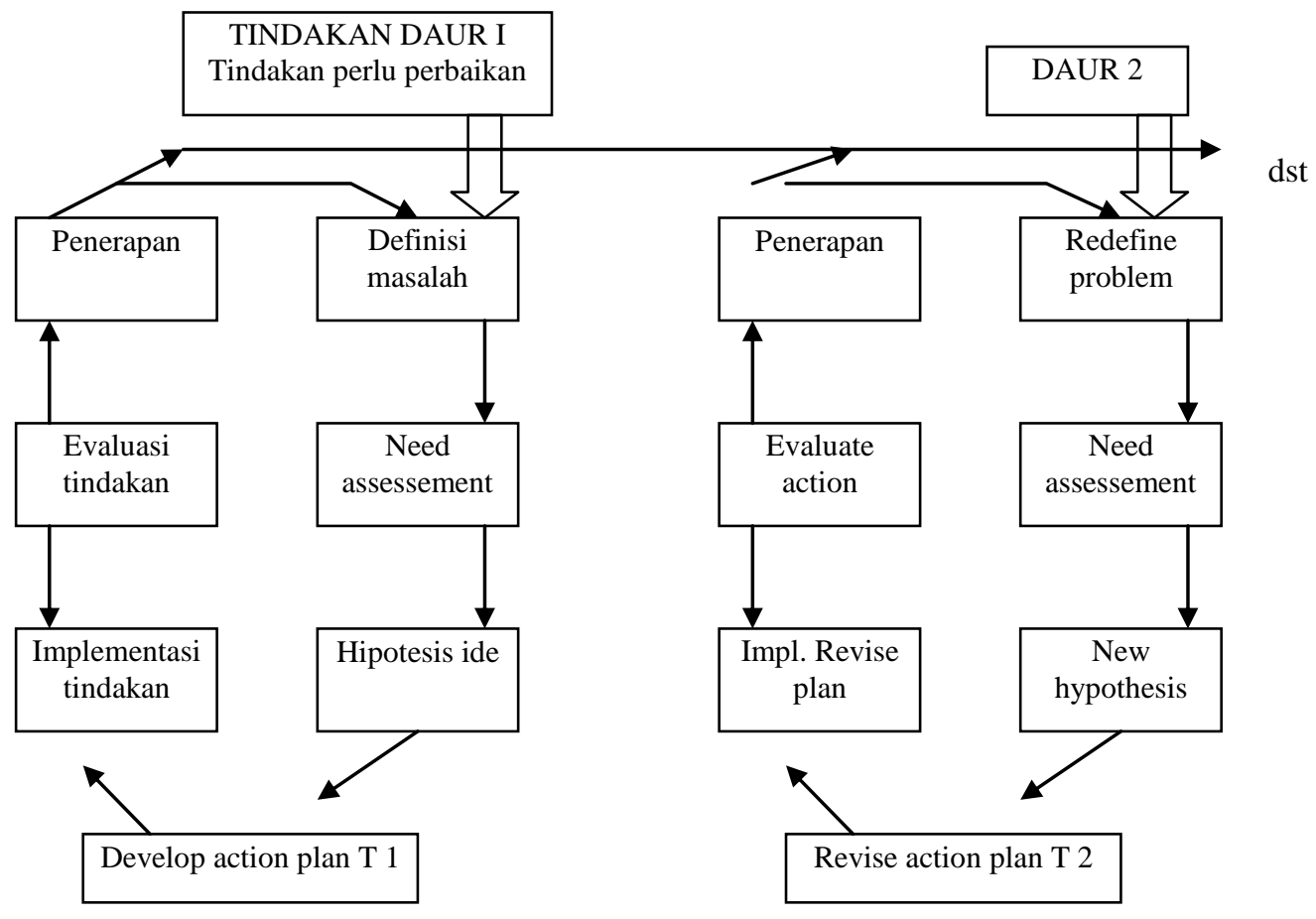

(dalam Sukidin, Basrowi, Suranto, 2002: 54)

Gambar 1. Penelitian Tindakan Model Mc. Kernan, 1991 


\section{Prosedur :}

- Tindakan daur I : mulai dari definisi masalah, berlanjut ke assessment yang disiapkan,berlanjut kerumusan hipotesis, berlanjut kepengembangan untuk tindakan I, lalu implementasi tindakan, evaluasi tindakan berlanjut ke penerapan selanjutnya.

- Tindakan daur II : mulai dari menentukankembali masalah yang ada, berlanjut ke assessment yang disiapkan, terus kepemikiran terhadap munculnya hipotesis yang baru, perbaikan tindakan pada rencana ke 2, pelaksanaan tindakan, evaluasi terhadap semua pelaksanaan dan penerapan.

Data yang dikumpulkan pada penelitian ini adalah data prestasi belajar siswa pada permainan bola basket. Adapun instrument yang digunakan untuk mengumpulkan data prestasi belajar siswa pada permainan bola basket adalah unjuk kerja. Setelah data terkumpul, selanjutnya dilakukan analisis data menggunakan analisis deskriptif kuantitatif.

\section{Hasil dan Pembahasan}

Salah satu permainan yang dibelajarakan pada mata pelajaran olahraga adalah Bola Basket. Bola Basket adalah olahraga bola berkelompok yang terdiri atas dua tim beranggotakan masing-masing lima orang yang saling bertanding mencetak poin dengan memasukkan bola ke dalam keranjang lawan. Bola basket sangat cocok untuk ditonton karena biasa dimainkan di ruang olahraga tertutup dan hanya memerlukan lapangan yang relatif kecil. Selain itu, bola basket mudah dipelajari karena bentuk bolanya yang besar, sehingga tidak menyulitkan pemain ketika memantulkan atau melempar bola tersebut.

Permainan bola basket adalah persegi panjang dengan ukuran panjang lapangan yaitu 26 meter serta lebar lapangan yaitu 14 meter. Tiga buah lingkaran yang terdapat di dalam lapangan basket memiliki panjang jari-jari yaitu 1,80 meter. Jumlah pemain dalam permainan bola basket adalah 5 orang dalam satu regu dengan cadangan 5 orang. Sedangkan jumlah wasit dalam permainan bola basket adalah 2 orang. Wasit 1 disebut Referee sedangkan wasit 2 disebut Umpire. Waktu permainan $4 \times 10$ menit. Di antara babak $1,2,3$, dan babak 4 terdapat waktu istirahat selama 10 menit. Bila terjadi skor yang sama pada akhir pertandingan harus diadakan perpanjangan waktu sampai terjadi selisih skor. Di antara dua babak tambahan terdapat waktu istirahat selama 2 menit. Waktu untuk lemparan ke dalam yaitu 5 detik.

Dalam membelajarkan permainan Bola Basket kepada siswa, dapat menerapkan metode pembelajaran kontekstual. Trianto (2007 : 5), menyatakan bahwa dalam konteks pendidikan, metode pembelajaran adalah suatu pola yang digunakan sebagai pedoman dalam merencanakan pembelajaran di kelas atau pembelajaran tutorial dan untuk menentukan perangkat-perangkat komputer, kurikulum, dan lain-lain. Sedangkan Nurhadi (2004 : 13) menyatakan bahwa pembelajaran kontekstual adalah konsep belajar dimana guru menghadirkan dunia nyata ke dalam kelas dan mendorong siswa membuat hubungan antara pengetahuan yang dimilikinya dengan penerapannya dalam kehidupan mereka sehari-hari, sementara siswa memperoleh pengetahuan dan keterampilan dari konteks yang terbatas, sedikit demi sedikit, dan dari proses mengkonstruksi sendiri sebagai bekal untuk memecahkan masalah dalam kehidupannya sebagai anggota masyarakat.

Penerapan metode pembelajaran kontekstual pada pembelajaran permainan bola basket sangat efektif dilakukan. Hal tersebut dikarenakan siswa dapat melihat secara langsung bagaimana cara bermain bola basket. Kegiatan seperti ini membuat siswa lebih mudah mengerti dan memahami permainan bola basket. Hasil ini terbukti dari meningkatnya prestasi belajar siswa pada permainan bola basket. Adapun hasil penelitian pada penelitian ini adalah sebagai berikut.

1). Hasil yang diperoleh dari kegiatan awal:

Hasil siklus awal diperolehan nilai rata rata kelas prestasi belajar penjaskes masih sangat rendah, yaitu dengan perolehan skor nilai secara klasikal yaitu 2490 dan rata rata kelas 69,16 dimana siswa yang mencapai persentase ketuntasan belajar $36,11 \%$, dan yang 
tidak mencapai ketuntasan adalah $63,88 \%$, dengan tuntutan KKM untuk mata pelajaran penjaskes kelas IX B SMP Negeri 2 Gianyar adalah dengan nilai 75.

2). Hasil pada siklus I:

Pada siklus I sudah diupayakan untuk perbaikan pembelajaran untuk meningkatkan prestasi belajar penjaskes dengan menggunakan metode pembelajaran kontekstual. Peneliti telah giat melakukan kegiatan yang susuai dengan kebenaran teori yang ada sehingga peneliti memperoleh hasil yang lebih baik dari proses awal, yaitu dengan rata-rata nilai 74,44 dari jumlah nilai secara klasikal 2680 seluruh siswa di kelas IX B, dan prosentase ketuntasan belajarnya adalah $75 \%$, yang tidak tuntas adalah $25 \%$. Hasil ini belum maksimal, karena belum mecapai indikator keberhasilan penelitian yang mencanangkan dengan minimal prosentase ketuntasan belajar $85 \%$.

3). Pada siklus II,

Dengan tindakan yang sangat maksimal dan pelaksanaan yang betul-betul mengikuti kebenaran teori sesuai dengan metode pembelajaran kontekstual dalam pembelajaran penjaskes di kelas IX B SMP Negeri 2 Gianyar, dimana hasil yang diperoleh pada siklus II ini ternyata prestasi belajar penjaskes meningkat secara signifikan dengan nilai rata-rata 82,77 dan ketuntasan belajarnya adalah $97 \%$. Dari keseluruhan jumlah siswa yaitu 36 orang siswa 25 orang siswa telah mampu melampaui nilai KKM yaitu 75.

Semua hasil yang diperoleh dari awal, siklus I dan siklus II dipaparkan dalam bentuk tabel dan grafik seperti berikut:

Tabel 1. Tabel Data Prestasi Belajar Siswa kelas IX B SMP Negeri 2 Gianyar

\begin{tabular}{llllll}
\hline DATA & AWAL & SIKLUS I & SIKLUS II & VARIABEL & \\
\hline Skor Nilai & 2490 & 2680 & 2980 & Prestasi & Belajar \\
\cline { 1 - 4 } Rata-Rata Kelas & 69,16 & 74,44 & 82,77 & Penjasorkes & dengan \\
\cline { 1 - 5 } Presentase Ketuntasan & $36,11 \%$ & $75 \%$ & $97 \%$ & KKM 75 & \\
\hline
\end{tabular}

Tabel di atas, dapat digambarkan pada grafik histogram berikut ini.

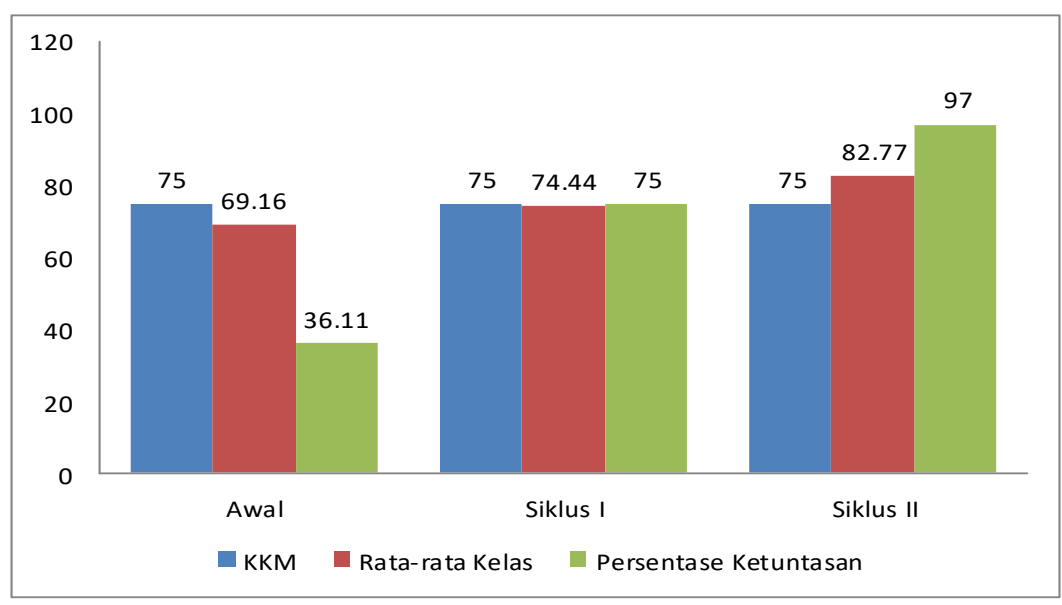

Gambar 2: Grafik Histogram Prestasi Belajar Penjasorkes Siswa Kelas IX B Semester I Tahun Pelajaran 2017/2018 SMP Negeri 2 Gianyar

Hasil penelitian ini sejalan dengan hasil penelitian yang dilakukan oleh Utami (2014) yang berjudul penerapan metode pembelajaran Contextual Teaching And Learning (CTL) pada mata pelajaran TIK untuk mengukur peningkatan hasil belajar siswa kelas XII IPS di SMA Negeri 1 Suruh. Dalam penelitiannya dinyatakan bahwa: Model pembelajaran CTL diterapkan pada kelompok eksperimen dan didapatkan hasil nilai post-test yang lebih tinggi daripada nilai pre-test. Selain dengan menerapkan pembelajaran CTL, siswa mengalami 
perubahan sikap menjadi lebih aktif dan kreatif. Sehingga dapat disimpulkan bahwa penerapan metode pembelajaran CTL dapat meningkatkan keaktifan siswa yang dapat mempengaruhi atau meningkatkan hasil belajar siswa.

Selanjutnya hasil penelitian yang dilakukan oleh Subhan (2013) yang berjudul penerapan pendekatan Contextual Teaching And Learning (CTL) terhadap hasil belajar dribble bola basket (studi pada siswa kelas VIIIA SMP IT Babussalam Probolinggo). Pada penelitiannya dinyatakan bahwa: ada peningkatan hasil belajar teknik dasar dribble bola basket siswa antara sebelum dan sesudah pembelajaran dengan pendekatan CTL di SMP IT Babussalam Probolinggo. Hal ini berdasarkan hasil uji beda atau uji t yang menghasilkan thitung lebih besar dari t-tabel $(13,72>1,71)$ pada taraf signifikansi $5 \%$ dan $13,72>2,49$ pada taraf signifikansi $1 \%$.

Berdasarkan pemaparan di atas, dapat disimpulkan bahwa metode pembelajaran kontekstual dapat meningkatkan prestasi belajar permainan bola basket siswa kelas IX B SMP Negeri 2 Gianyar.

\section{Simpulan dan Saran}

Setelah dilakukan perbaikan pembelajaran dengan metode pembelajaran kontekstual, dapat ditarik kesimpulan bahwa prestasi belajar mata pelajaran Penjasorkes dapat ditingkatkan. Melihat hasil penelitian yang disampaikan di Bab IV dan semua data yang diperoleh, maka tujuan penelitian ini sudah terpenuhi dengan bukti sebagai berikut. 1) Pada awalnya ada 23 siswa mendapat nilai di bawah KKM pada siklus I menurun menjadi 9 siswa dan siklus II hanya ada 1 siswa mendapat nilai di bawah (KKM), 2) Nilai rata-rata awal 69,16 naik menjadi 74,44 pada siklus I dan pada siklus II naik menjadi $82,77,3$ ) Prosentase ketuntasan belajar awal siswa hanya $36,11 \%$ sedangkan pada siklus I menjadi lebih banyak yaitu $75 \%$ dan pada siklus II menjadi cukup banyak yaitu $97 \%$.

Dengan terjadinya kenaikan prestasi belajar sesuai harapan maka dapat disampaikan bahwa rumusan masalah dan tujuan penelitian sudah mampu dipenuhi. Dari perolehan bukti tersebut dapat disimpulkan juga bahwa hipotesis penelitian yang diajukan sudah dapat diterima.

Dengan telah berhasil penelitian ini maka disampaikna saran-saran sebagai berikut: 1) Kepada teman guru pengajar mata pelajaran Penjasorkes disarankan mencoba metode pembelajaran kontekstual, 2) Kepada Kepala Sekolah disarankan untuk untuk memberi penekanan agar guru mau melaksanakan pembelajaran dengan langkah-langkah model yang sudah diteliti, 3) Dalam melaksanakan proses pembelajaran pada mata pelajaran Penjasorkes penggunaan metode pembelajaran kontekstual semestinya menjadi pilihan dari beberapa model yang ada mengingat model ini telah terbukti dapat meningkatkan kerjasama, berkreasi, bertindak aktif, bertukar informasi, mengeluarkan pendapat, bertanya, berdiskusi, berargumentasi dan lain-lain, 4) Walaupun penelitian ini sudah dapat membuktikan efek utama dari metode pembelajaran kontekstual dalam meningkatkan prestasi belajar, sudah pasti dalam penelitian ini masih ada hal-hal yang belum sempurna dilakukan, oleh karenanya kepada peneliti lain yang berminat meneliti topik yang sama untuk meneliti bagian-bagian yang tidak sempat diteliti. Demi kesempurnaan penelitiaan ini, peneliti mengharapkan kritik, saran, masukan yang konstruktif sehingga diharapkan bagi peneliti lain untuk melakukan penelitian lanjutan.

\section{Daftar Rujukan}

Aip Syarifuddin dan Muhadi. 1992. Pendidikan Jasmani dan Kesehatan. Jakarta: Depdikbud.

Basrowi dan Sukidin. 2002. Metode Penelitian Kualitatif Perspektif Mikro. Surabaya: Insan Cendikia. 
Dian Tri Handayani. 2007. Meningkatkan Hasil Belajar Matematika pada Pokok Bahasan Segitiga melalui Model Pembelajaran Contextual Teaching and Learning (CTL) Berbasis Inquiry dengan pemanfaatan LKS (Lembar Kerja Siswa) pada Peserta Didik Kelas VII Semester II SMP 1 Semarang Tahun Pelajaran 2006/2007. Semarang: UNNES.

Erwin, Herlina. 2018. Penerapan Pendekatan Kontekstual Untuk Meningkatkan Minat Dan Prestasi Belajar Siswa Pada Pelajaran IPA. Jurnal: Pendidikan Dasar Perkhasa Volume 4, Nomor 1, April 2018.

Gita, I Nyoman. 2007. Implementasi Pendekatan Kontekstual Untuk Meningkatkan Prestasi Belajar Matematika Siswa Di Sekolah Dasar. Jurnal Penelitian dan Pengembangan Pendidikan 1(1): 26-34

Hana, Putri. 2017. Peningkatan Keterampilan Menulis Puisi Bebas Menggunakan Pendekatan Kontekstual Siswa Sekolah Dasar. PGSD. Fakultas IImu Pendidikan. Universitas Pahlawan Tuanku. Tambusai Riau. Jurnal Publikasi Pendidikan http://ojs.unm.ac.id/index.php/pubpend. Volume 7 Nomor 2, Juni 2017

Muslich, Masnur. (2007). KTSP Pembelajaran Berbasis Kompetensi dan Kontekstual. Jakarta: Bumi Aksara

Nurhadi, dkk. 2003. Pembelajaran Kontekstual dan Penerapannya dalam KBK. Malang: Universitas Negeri Malang.

Rasiman, Wahyu Widayanto. 2008. Penerapan Pendekatan Kontekstual Untuk Meningkatkan Prestasi Belajar Matematika Pada Materi Lingkaran Bagi Siswa Kelas VIII C Smp Negeri 1 Karangawen Demak.

Rufaida, Ida. (2009). Meningkatkan Kemampuan Pemecahan masalah Matematika Melalui Pendekatan Kontekstual dalam Pembelajaran Matematika (Penelitian Tindakan Kelas Terhadap Siswa Kelas VIII SMP Negeri 1 Cicalengka Kabupaten Bandung. Skripsi. Jurusan Pendidikan Matematika STKIP Garut. (tersedia pada http://ml.scribd.com/doc/21218804/lda-Rufaida-PTK-Matematika-Kontekstual).

Diunduh pada tanggal 9 Januari 2013.

Santoso, Erik. (2017). Penggunaan Model Pembelajaran Kontekstual Untuk Meningkatkan Kemampuan Pemahaman Matematika Siswa Sekolah Dasar. Jurnal Cakrawala Pendas Vol. 3 No.1 Edisi Januari 2017

Suarjani, D.N. (2010). Penerapan Model Pembelajaran Kontekstual Berbasis Masalah untuk Meningkatkan Aktivitas dan Prestasi Belajar IPA pada Siswa Kelas IV SDN 1 Ringdikit Tahun Pelajaran 2008/ 2009. Tesis(tidak diterbitkan). Program Pasca Sarjana, Universitas Pendidikan Ganesha.

Subhan, Muhammad. 2013. Penerapan Pendekatan Contextual Teaching And Learning (CTL) Terhadap Hasil Belajar Dribble Bola Basket (Studi Pada Siswa Kelas VIIIA SMP IT Babussalam Probolinggo). Jurnal Pendidikan Olahraga dan Kesehatan Volume 01 Nomor 03 Tahun 2013, 689 - 693 Unesa.

Trianto, 2007. Model-model Pembelajaran Inovatif Berorientasi Kontruktivistik. Jakarta: Prestasi Pustaka. 
Utami, Diah Oktie. 2014. Penerapan Metode Pembelajaran Contextual Teaching And Learning (CTL) pada Mata Pelajaran TIK untuk Mengukur Peningkatan Hasil Belajar Siswa Kelas XII IPS di SMA Negeri 1 Suruh. Artikel IImiah. Program Studi Pendidikan Teknik Informatika Dan Komputer Fakultas Teknologi Informasi Universitas Kristen Satya Wacana Salatiga

Widiasa, I Ketut. (2007). Peningkatan Keterampilan Menulis Naratif dalam Pembelajaran Bahasa Indonesia dengan Penerapan Pendekatan Kontekstual Di Kelas X-6 Semester genap tahun pelajaran 2006/2007 di SMA Negeri. Universitas Negeri Malang. (tersedia pada http://library.um.ac.id/index.php/Artikel-PTK/laporanptk.html). Diunduh pada tanggal 9 Januari 2013. 